\title{
Morphological and anatomical studies on some species of Polygonaceae in Egypt
}

\author{
Fatema S. Mohamed \\ Flora and Phytotaxonomy Researches Dept., Horticultural Researches Institute, ARC., Egypt \\ E-mail: fatmafouadsami@gmail.com
}

\section{Safwat A. Azer}

Flora and Phytotaxonomy Researches Dept., Horticultural Researches Institute, ARC., Egypt E-mail: safwat.azer@arc.sci.eg

\section{Received: 10 Oct. 2019 / Accepted 22 Dec. 2019 / Publication date: 15 Jan. 2020}

\begin{abstract}
The taxonomic relationships among eight species of Polygonaceae; Persicaria senegalensis (Meisn.) Soják., Rumex dentatus L., Rumex vesicarius L., Calligonum polygonoides L., Antigonon guatimalense Meisn., Antigonon leptopus Hook. \& Arn., Ruprechtia laxiflora Meisn. and Ruprechtia salicifolia (Cham. \& Schltdl.) C.A. Mey. have been concentrated on the basis of information derived from macro- and micro-morphological characters. These diagnostic characters appeared to be significant in differentiation among the studied species. The present work recorded important features in the blade outline, ochreae shape, perianth structure and fruit appendages. The stem outline ranged from terete, ovoid with wavy margin and pentagonal. Pericycle showed two types; parenchymatous and fibrous. Vascular structure of stem appeared either a continuous ring or isolated bundles. The outline of the petiole demonstrates that the studied species can be distinguished into four patterns (semi-terete with wavy margin, half circle with wavy margin, half circle with two projections and oval). Also the stomata revealed three main types; Anomocytic, anisocytic and paracytic. This work showed that the studied species recorded five types of non-glandular trichomes and three types of glandular trichomes. A dichotomous indented key to the species is constructed. The data recorded from the morphological and anatomical characters are used in numerical analysis. This analysis showed that species were grouped into two major clusters, the first one (I) consisted of one species; Calligonum polygonoides while the second cluster (II) included the remainders.
\end{abstract}

Keywords: Polygonaceae, macro-morphological characters, micro-morphological characters, numerical analysis

\section{Introduction}

Polygonaceae is a family of flowering plants known as the knotweed family. The name is based on the genus Polygonum, and was first used by Antoine Laurent de Jussieu in 1789 in his book, Genera Plantarum. The name of the family refers to the many swollen nodes on the stems of some species (Jussieu 1789).

Polygonaceae contained approximately 48 genera and 1,200 species. The largest genera are Eriogonum (240 species), Rumex (200 species), Coccoloba (120 species), Persicaria (100 species) and Calligonum (80 species) (Freeman \& Reveal 2005 and Sanchez and Kron, 2008). The members of Polygonaceae are widely distributed and most of the species are concentrated in the northern temperate region (Heywood, 1978). They are groups of morphologically different herbs, shrubs, small trees or climbers characterized by simple leaves with covering ochrear stipules, unilocular ovary and endospermic seeds (Hutchinson and DaLziel, 1954 and Brummitt 1992).

Metcalfe and Chalk (1950 and 1979) gave a comprehensive report on foliar anatomy of the Polygonaceae. Lersten and Curtis (1992) examined foliar anatomy of genus Polygonum and described numerous anatomical features of the leaves (their variations and distribution patterns).Their studies were carried out on 153 species of Polygonum sensu lato representing all sections of the genus.

Corresponding Author: Fatema S. Mohamed, Flora and Phytotaxonomy Researches Dept., Horticultural Researches Institute, ARC. E-mail: fatmafouadsami@gmail.com 
Ayodele and Olowokudejo (2006) made comparative studies on the leaf epidermal features of five tribes including 19 species of family Polygonaceae in West Africa. Noor et al., (2011) studied the foliar anatomical characters of Polygonum minus Huds to determine its taxonomic significance.

Jaretzky (1925) named two subfamilies: Eriogonoideae and Polygonoideae, including Coccoloboideae within the latter. The family was made up of more than two subfamilies, with various authors differing in their circumscriptions of the subfamilies (Bentham and Hooker, 1880; Buchinger, 1957 and Takhtajan, 1980). Roberty and Vautier (1964) divided the family again into three subfamilies, but this time the groups were Polygonoideae, Eriogonoideae, and Calligonoideae. The classification of Polygonaceae at and above the generic level has been unstable over the years. Haraldson, 1978 recognised two subfamilies; Polygonoideae based on Polygonum L. and Eriogonoideae based on Eriogonum Mich. Reveal (1989); Brandbyge (1992) and Freeman and Reveal (2005) used the two-subfamily division proposed earlier by Jaretzky (1925). The tribal treatment of Polygonum sensu lato has been varied since the time of Linnaeus (1753). Several authors placing the segregate taxa contained into different tribes and subfamilies (Ronse Decraene and Akeroyd, 1988).

The comprehensive revision of the family was published by Brandbyge in 1992 as a part of "The Families and Genera of Vascular Plants". Brandbyge (1992) followed earlier systems of plant classification in dividing Polygonaceae into two subfamilies, Eriogonoideae and Polygonoideae. The circumscriptions of these two subfamilies have been changed in light of phylogenetic studies of DNA sequences. Genera related to Coccoloba and Triplaris were moved from Polygonoideae to Eriogonoideae. The genus Symmeria does not belong to either of these subfamilies because it is sister to the rest of the family. Sanchez et al., 2011 divided the subfamily Polygonoideae into five tribes, Calligoneae, Fagopyreae, Persicariae, Polygoneae and Rumiceae, leaving some genera unplaced. Schuster et al., 2015 studied the molecular phylogenetic and added two new tribes namely Oxygoneae and Pteroxygonea.

The main purpose of the present study is to use macro- and micro-morphological criteria to detect the morphological variability among the studied species of Polygonaceae growing in Egypt. This study has the following objectives:

a) To evaluate the morphological criteria of the studied species and their sharing in the discrimination among them.

b) To reveal the important role of numerical study in the analysis of the data derived from the variations among the species.

\section{Materials and Methods}

The present study is based on 8 species of Polygonaceae collected fresh from different localities in Egypt (Table I). In this work the studied materials were identified by means of comparison with specimens kept in the herbarium of Flora and Phytotaxonomy Researches department (CAIM). In addition to some references of cultivated plants and Flora of Egypt were used as; Bailey (1949), Lindley (1932), Hutchinson and Dalziel (1954), Tãckholm (1974), Pandey (1997), and Boulos (1999). Voucher specimens of studied species were prepared and kept in the herbarium of Flora and Phytotaxonomy Researches department (CAIM) during September 2017 till September 2018.

Table 1: List of the collected species for the present study.

\begin{tabular}{ll}
\hline Species & Locality and date \\
\hline Persicaria senegalensis (Meisn.) Soják. & El- Qaluobea . Marc, 2018 \\
Rumex dentatus L. & El- Qaluobea . Marc, 2018 \\
Rumex vesicarius L. & El- Qaluobea . Marc, 2018 \\
Calligonum polygonoides L. & Alexandria. June 2018 \\
Antigonon guatimalense Meisn. & Mazhar Garden, 20/5/2018. \\
$\begin{array}{l}\text { Antigonon leptopus Hook. \& Arn. } \\
\text { Ruprechtia laxiflora Meisn. }\end{array}$ & Mazhar Garden, 20/5/2018. \\
Ruprechtia salicifolia (Cham. \& Schltdl.) C.A. Mey.. & Mazhar Garden, 20/5/2018. \\
\hline
\end{tabular}


Table 2: The taxonomic treatment of the studied species in the system of A. Engler according to Melchior (1964).

\begin{tabular}{lll}
\hline Subfamily & Tribe & Species \\
\hline \multirow{2}{*}{ Polygonoideae } & Persicarieae & Persicaria senegalensis \\
& Rumiceae & Rumex dentatus \\
& Rumex vesicarius \\
& Atraphaxidinae & $\begin{array}{l}\text { Antigonum } \text { polygonoides } \\
\text { Antigonon leptopulense }\end{array}$ \\
\hline \multirow{2}{*}{ Coccoloboideae } & Coccolobeae & Ruprechtia laxiflora \\
& Ruprechtia salicifolia \\
\hline
\end{tabular}

The herbarium specimens were examined, photographed and kept in the herbarium of the Flora and Phytotaxonomy Researches Department (CAIM). The morphological characters of collected specimens of studied taxa were studied. For anatomical investigation each specimen was fixed according to Nassar and El Sahhar, (1998) in F.A.A. (formalin - glacial acetic acid - 70\% ethyl alcohol) with the ratio of 5: 5: 90 by volume. Stems and leaves (petiole \& blade) were hand sectioned at 20-30 $\mathrm{m} \mu$. The sections were stained according to Dilcher (1974) in safranin (1\% solution in $50 \%$ ethanol) and light green (1\% solution in $96 \%$ ethanol) and photographs. The relationship among the studied taxa has been analyzed using Average Linkage (Between Groups) of SPSS program version 22.

\section{Results and Discussion}

\section{I- Morphological Aspects}

\section{a- Macro- morphological Aspects}

The different macro- morphological features of studied species were extensively investigated to indicate the importance of these characters. Variation in these aspects among the species is listed in Table 3 and illustrated in Plates $1 \& 2$.The results were used to build a dichotomous indented key to the investigated species.

A- Leafless plant, fruit spiny Calligonum polygonoides

AA- Leafy plant, fruit not spiny

B- Climber plant with tendril

C- The outer sepals are cordate, leaves 3-3.5 cm wide... Antigonon leptopus

CC- The outer sepals are ovate, leaves $4.5-5 \mathrm{~cm}$ wide ........Antigonon guatimalense

BB- Erect plant without tendril

D- Fruit winged

E- Leaf is ovate-deltoid, nutlet is ovoid. Rumex vesicarius

EE- Leaf is oblong-lanceolate, nutlet is trigonous Rumex dentatus

DD- Fruit not winged

G- Herb ......

\section{Persicaria senegalensis}

\section{GG- Shrub}

H- Leaf lanceolate Ruprechtia salicifolia

HH- Leaf elliptic. Ruprechtia laxiflora 
Table 3: Summary table and Data coding of macro- morphological characters of the studied species

Characters

\begin{tabular}{|c|c|c|c|c|c|c|c|}
\hline Species & 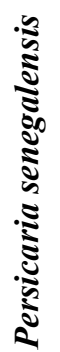 & 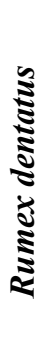 & 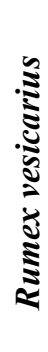 & 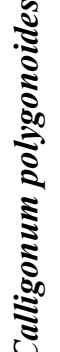 & 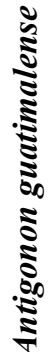 & 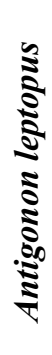 & 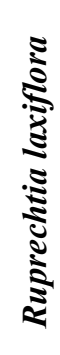 \\
\hline
\end{tabular}

1- Habit: Herb [1], shrub [2].

2- Stem: Erect [1] / climber [2].

3- Stem branching: Branched from the base [1]/ branched above [2].

4- Leaf margin: Entire [1]/ erenulate [2]/ undulate [3].

5- Leaf appearance: Smooth [1]/ chartaceous [2]/ rugose [3].

6 - Blade outline: Lanceolate [1]/ Obovate-deltoid [2]/

cordate [3]/ oblong [4].

7- Blade apex: Acute [1]/ obtuse [2]/ Acuminate [3] /

Truncate [4].

8- Blade base: Symmetric [1]/ A symmetric [2].

9- Blade length: Short $(2-5 \mathrm{~cm})$ [1]/ long $(10-20 \mathrm{~cm})$ [2].

10- Ocreae: Two lobed membranous [1]/ not fringed [2], scaly [3].

11- Petiole: Very short (3- $4 \mathrm{~mm})$ [1]/ long $(3-5 \mathrm{~cm})$ [2]/

very long $(7-9 \mathrm{~cm})[3]$.

12- Inflorescence: Racemes [1]/ cymes [2].

13- Flower: Unisexual [1]/ bisexual [2].

14- Perianth: 6- segments [1]/ 5- segments [2].

15- Perianth color: Pink [1]/ green [2].

16- Stamens: 6 [1]/ 8 [2]/ 16 [3].

17- Style: 3 [1]/ 4 [2].

18- Fruit appendages: With spines [1]/ with wing [2]/ without appendages [3].

19- Nutlet shape: Trigonous [1]/ flattened [2]/ ovoid [3]

20- Nutlet length: Short (2-3 mm) [1]/ long (6-12 mm) [2].

21- Nutlet color: Brown [1]/ white [2].

\begin{tabular}{llllllll}
1 & 1 & 1 & 2 & 2 & 2 & 2 & 2 \\
1 & 1 & 1 & 1 & 2 & 2 & 1 & 1 \\
2 & 1 & 1 & 2 & 2 & 2 & 2 & 2 \\
1 & 1 & 1 & 0 & 2 & 3 & 1 & 3 \\
1 & 1 & 1 & 0 & 2 & 3 & 1 & 1 \\
1 & 4 & 2 & 0 & 3 & 3 & 4 & 1 \\
3 & 2 & 2 & 0 & 3 & 1 & 1 & 1 \\
2 & 2 & 1 & 0 & 1 & 1 & 1 & 1 \\
2 & 2 & 1 & 0 & 1 & 1 & 1 & 1 \\
2 & 3 & 3 & 1 & 1 & 1 & 2 & 2 \\
& & & & & & & \\
1 & 3 & 3 & 0 & 2 & 2 & 1 & 1 \\
1 & 1 & 1 & 2 & 1 & 1 & 2 & 2 \\
2 & 2 & 2 & 2 & 2 & 2 & 1 & 1 \\
1 & 1 & 1 & 2 & 2 & 2 & 1 & 1 \\
1 & 1 & 1 & 1 & 1 & 1 & 2 & 2 \\
2 & 3 & 1 & 1 & 2 & 2 & 2 & 2 \\
2 & 1 & 1 & 1 & 1 & 1 & 2 & 2 \\
3 & 2 & 2 & 1 & 3 & 3 & 3 & 3 \\
2 & 3 & 3 & 3 & 1 & 1 & 1 & 1 \\
1 & 1 & 1 & 2 & 2 & 2 & 1 & 1 \\
1 & 1 & 1 & 2 & 1 & 1 & 1 & 1 \\
\hline & & & & & &
\end{tabular}

The morphological characters were found diagnostic to the investigated species. The studied species were herbs in Persicaria senegalensis, Rumex dentatus and Rumex vesicarius while were trees in the others. The stem was climber in Antigonon guatimalense and Antigonon leptopus and erect in the rest. Calligonum polygonoides was leafless but the other species were leafy. Leaf appearance was chartaceous in Antigonon guatimalense, rugose in Antigonon leptopus and smooth in the remainders. Blade outline ranged from lanceolate in Persicaria senegalensis and Ruprechtia salicifolia. obovate-deltoid in Rumex vesicarius only, cordate in Antigonon guatimalense and Antigonon leptopus and oblong in the rest. Fruit with spines in Calligonum polygonoides only, winged in Rumex dentatus and Rumex vesicarius while without appendages in the remainders. Nutlet shape was flattened in Persicaria senegalensis, ovoid in Rumex vesicarius, Rumex dentatus and Calligonum polygonoides while trigonous in the remainders. 


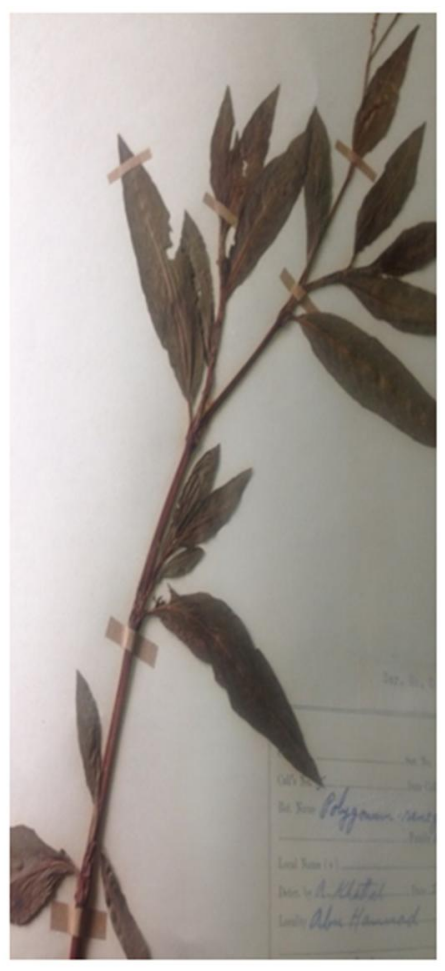

Persicaria senegalensis

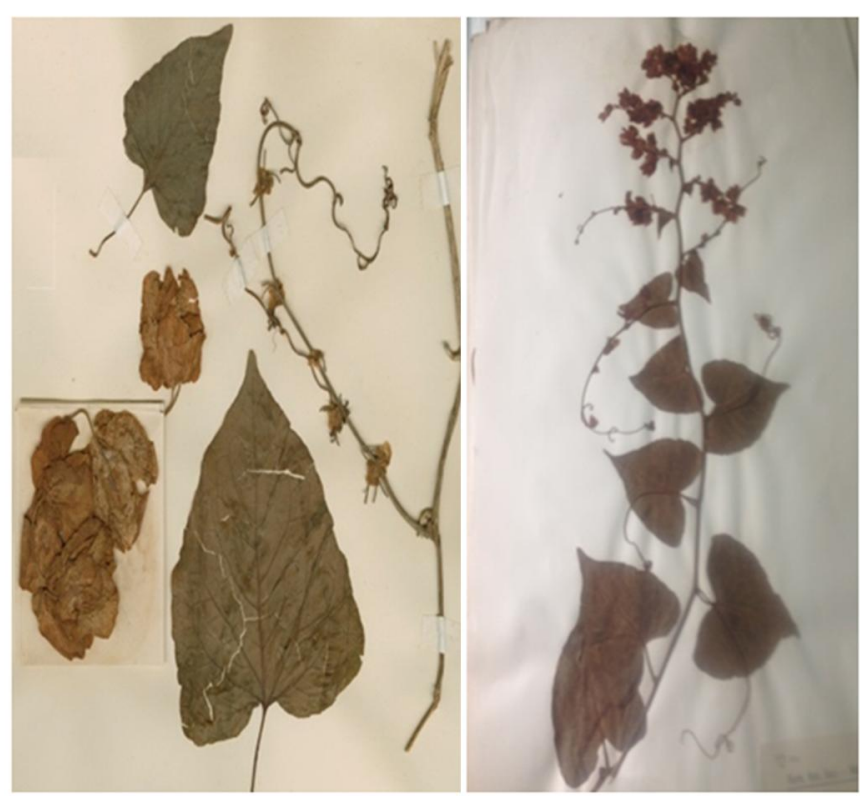

Antigonon guatimalense

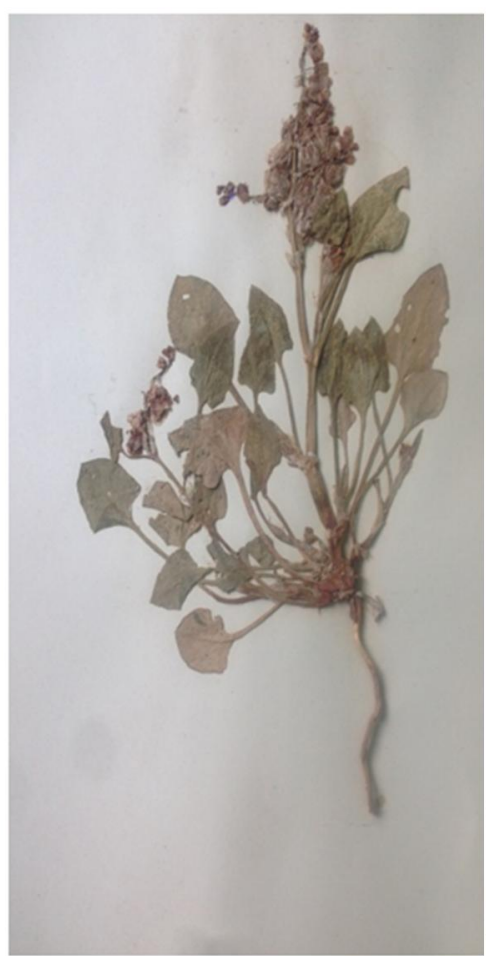

Rumex vesicarius

Antigonon leptopus

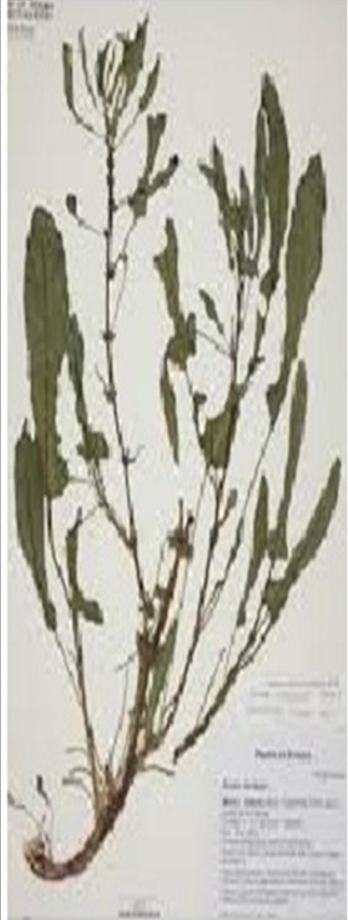

Rumex dentatus

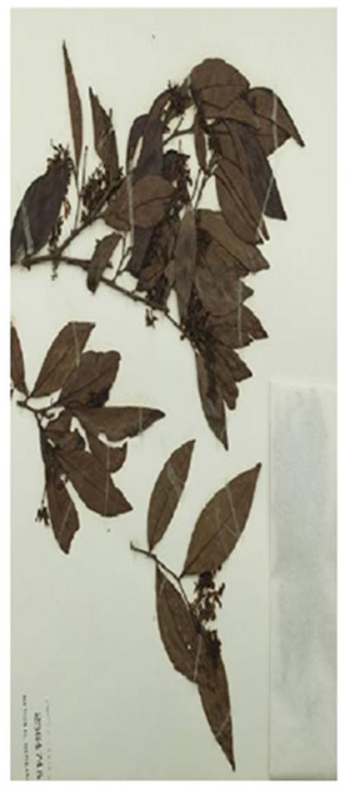

Ruprechtia laxiflora

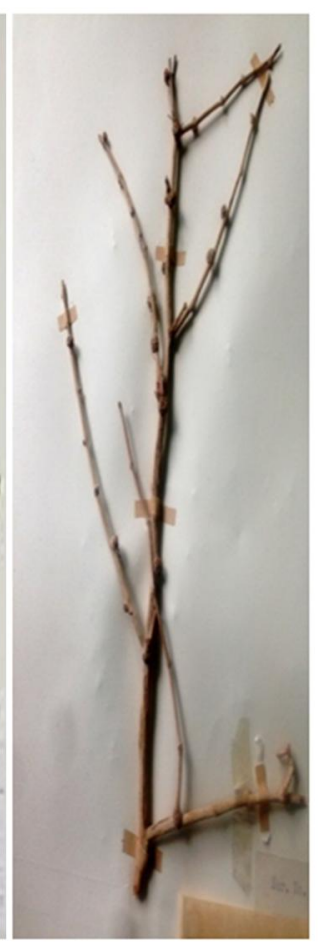

Calligonum polygonoides

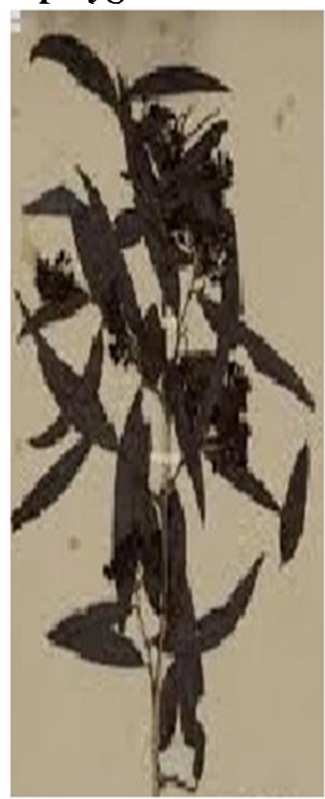

Ruprechtia salicifolia

Plate 1: Herbarium specimens of the studied species 

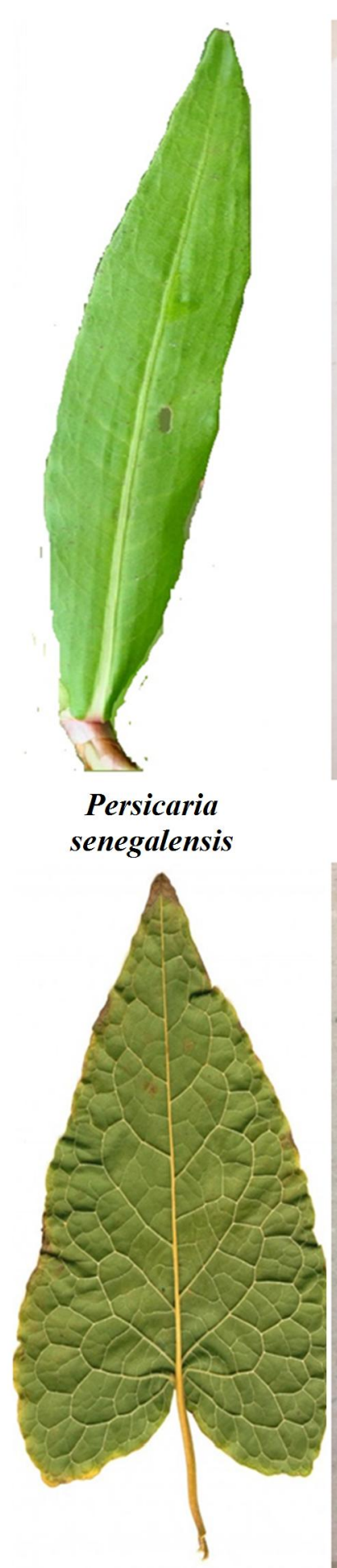

Antigonon leptopus

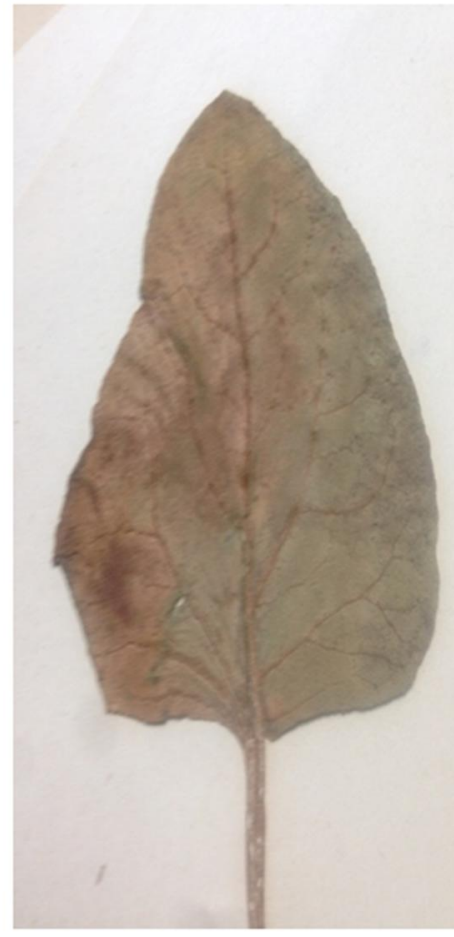

Rumex vesicarius

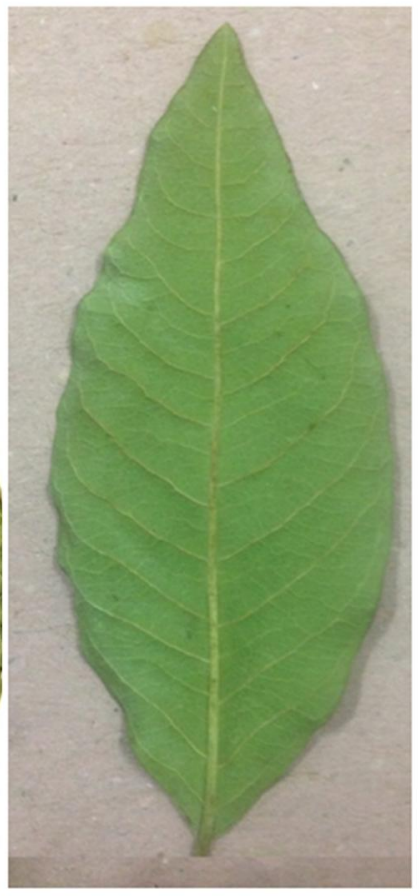

Ruprechtia laxiflora

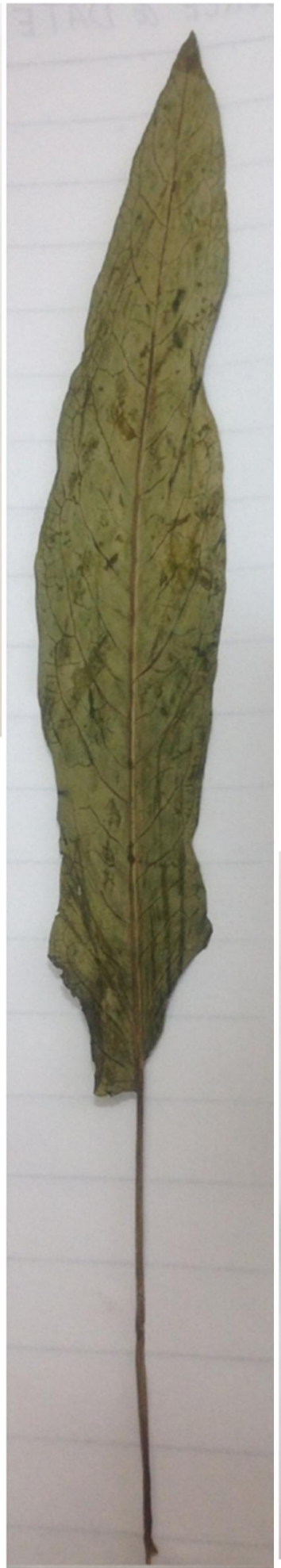

Rumex dentatus

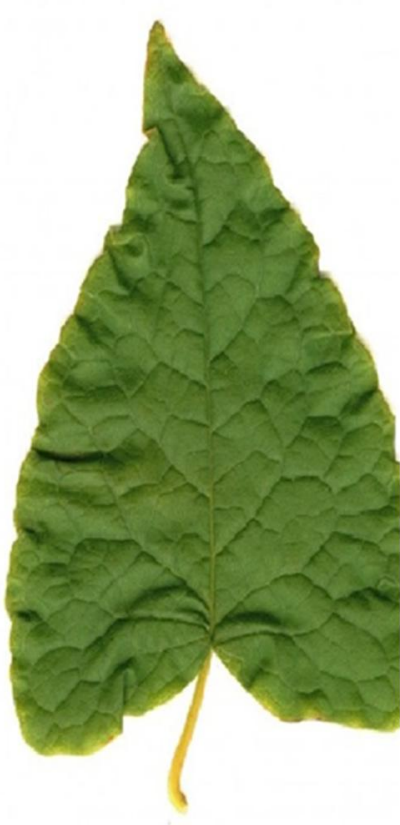

Antigonon guatimalense

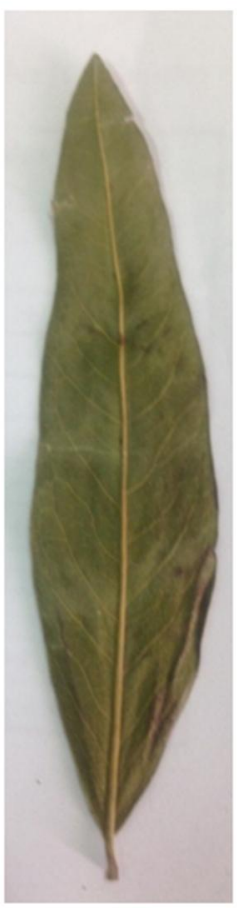

Ruprechtia salicifolia

Plate 2: Leaf of the studied species 


\section{b- Micro- morphological Aspect}

Micro-morphological investigation included the anatomical aspects of stem and leaf (petiole and blade). Also stomata and trichomes are included as shown in Table (4) and Plates (3, 4, 5, 6, 7 and 8).

Table 4: Summary table and Data coding of micro- morphological characters of the studied species

Characters

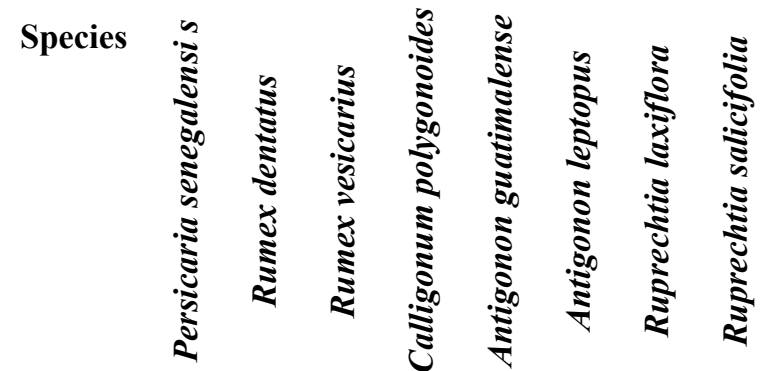

\begin{tabular}{|c|c|c|c|c|c|c|c|c|c|}
\hline \multirow{15}{*}{ Stem } & $\begin{array}{l}\text { 1- Outline: Terete [1]/ ovoid with wavy margin } \\
{[2] / / \text { pentagonal [3]. }}\end{array}$ & 2 & 2 & 2 & 1 & 3 & 3 & 1 & 1 \\
\hline & 2- Cuticle: Thick [1]/ very thick [2]. & 1 & 1 & 1 & 2 & 1 & 1 & 2 & 2 \\
\hline & 3- Cuticle: Smooth [1]/ warty [2]. & 1 & 1 & 1 & 2 & 1 & 1 & 1 & 1 \\
\hline & 4 Epidermal: Radial [1]/ tangentially [2]. & 1 & 2 & 2 & 1 & 1 & 2 & 2 & 2 \\
\hline & 5- Hypodermis: Present [1]/ absent [2]. & 2 & 2 & 2 & 1 & 1 & 1 & 1 & 1 \\
\hline & 6- Cortex: Wide [1]/ narrow [2]. & 2 & 2 & 2 & 1 & 2 & 2 & 2 & 2 \\
\hline & $\begin{array}{l}\text { 7-Cortex: One type of tissue [1]/ two types [2]/ } \\
\text { three types [3]. }\end{array}$ & 2 & 1 & 1 & 3 & 2 & 2 & 2 & 2 \\
\hline & 8-Druses in cortex: Present [1]/ absent [2]. & 2 & 2 & 2 & 1 & 1 & 1 & 1 & 1 \\
\hline & 9- Pericycle: Parenchyma [1]/ fibers [2]. & 2 & 1 & 1 & 2 & 2 & 2 & 2 & 2 \\
\hline & $\begin{array}{l}\text { 10- Vascular bundle: Continuous ring [1]/ } \\
\text { isolated bundles [2]. }\end{array}$ & 2 & 2 & 2 & 1 & 2 & 2 & 1 & 1 \\
\hline & 11- Phloem: Will defined [1]/ ill-defined [2]. & 1 & 2 & 2 & 1 & 1 & 1 & 1 & 1 \\
\hline & 12- Phloem: Patches [1]/ ring [2]. & 1 & 1 & 1 & 2 & 1 & 1 & 2 & 2 \\
\hline & 13- Pith: Homogenous [1]/ heterogeneous [2]. & 1 & 1 & 1 & 2 & 2 & 2 & 1 & 1 \\
\hline & 14- Pith: Solid [1]/ hollow [2]. & 2 & 1 & 1 & 1 & 1 & 1 & 1 & 1 \\
\hline & 15- Druses in pith: Present [1]/ absent [2]. & 2 & 1 & 1 & 1 & 2 & 1 & 1 & 1 \\
\hline \multirow{10}{*}{ Petiole } & $\begin{array}{l}\text { 16- Petiole outline: Semi-terete with wavy } \\
\text { margin [1]/ half-circular with wavy margin [2]/ } \\
\text { half-circular with two projections[3]/ oval [4]. }\end{array}$ & 2 & 1 & 1 & 0 & 3 & 3 & 4 & 4 \\
\hline & 17- Cuticle: Thick [1]/ very thick [2]. & 1 & 2 & 1 & 0 & 2 & 2 & 2 & 2 \\
\hline & 18- Cuticle: Smooth [1]/ warty [2]. & 1 & 1 & 2 & 0 & 1 & 1 & 2 & 2 \\
\hline & 19- Epidermis: Radial [1] / mixed [2]. & 1 & 2 & 2 & 0 & 1 & 1 & 1 & 1 \\
\hline & $\begin{array}{l}\text { 20- Main vascular bundles: One [1]/ more than } \\
\text { one [2]. }\end{array}$ & 2 & 1 & 1 & 0 & 1 & 1 & 1 & 1 \\
\hline & $\begin{array}{l}\text { 21- Splitting of vascular bundles: Present [1]/ } \\
\text { absent [2]. }\end{array}$ & 1 & 1 & 1 & 0 & 2 & 2 & 1 & 1 \\
\hline & $\begin{array}{l}\text { 22- Arrangement of vascular bundles: In a } \\
\text { circle [1]/ irregularly scattered [2]. }\end{array}$ & 1 & 2 & 2 & 0 & 2 & 2 & 1 & 1 \\
\hline & $\begin{array}{l}\text { 23- Bundle sheath: Wide parenchyma [1]/ } \\
\text { narrow parenchyma [2]. }\end{array}$ & 1 & 1 & 1 & 0 & 2 & 2 & 2 & 2 \\
\hline & $\begin{array}{l}\text { 24- Tissue associated: Collenchyma [1]/ fibers } \\
{[2] /}\end{array}$ & 1 & 1 & 1 & 0 & 2 & 2 & 2 & 2 \\
\hline & 25- Druses: Present [1]/ absent [2]. & 2 & 2 & 2 & 0 & 2 & 2 & 2 & 2 \\
\hline \multirow{5}{*}{ Blade } & 26- Cuticle: Thick [1]/ very thick [2]. & 2 & 2 & 2 & 0 & 1 & 1 & 1 & 1 \\
\hline & 27- Cuticle: Smooth [1]/ warty [2]. & 1 & 2 & 2 & 0 & 1 & 1 & 1 & 1 \\
\hline & 28- Epidermis: Radial [1] / mixed [2]. & 1 & 2 & 2 & 0 & 1 & 1 & 1 & 1 \\
\hline & $\begin{array}{l}\text { 29- Mesophyll: Dorsiventral [1]/ isobilateral } \\
\text { [2]. }\end{array}$ & 1 & 1 & 1 & 0 & 2 & 2 & 1 & 1 \\
\hline & 30- Vascular bundles sheath: Collenchyma [1]/ & 1 & 1 & 1 & 0 & 2 & 2 & 2 & 2 \\
\hline
\end{tabular}


sclerenchyma [2].

31- Main vascular bundles: One [1]/ more than one [2].

32- Subsidiary vascular bundles: $3[1] /$ more than 3 [2].

33- Schizogenous canals: Present [1]/ absent

[2].

34- Druses: Present [1]/ absent [2].

35- Stomata: Anomocytic [1]/ anisocytic [2]/ paracytic [3].

36- Unicellular papillose: Present [1]/ absent

[2].

37- Simple with long broad, blunt \& smooth

apical cell: Present [1]/ absent [2].

38- Simple with long broad, acute \& smooth apical cell: Present [1]/ absent [2].

Trichomes

39- Uniseriate: Present [1]/ absent [2].

40- Bristle: Present [1]/ absent [2].

41- Unicellular stalk and bicellular head:

Present [1]/ absent [2].

42- Short unicellular stalk and multicellular

head: Present [1]/ absent [2].

43- Sessile glands: Present [1]/ absent [2].

$\begin{array}{llllllll}1 & 1 & 1 & 0 & 2 & 2 & 2 & 2 \\ 2 & 1 & 1 & 0 & 1 & 1 & 2 & 2 \\ 1 & 1 & 1 & 0 & 1 & 1 & 2 & 2 \\ 1 & 1 & 1 & 0 & 1 & 1 & 1 & 1 \\ 3 & 1 & 1 & 0 & 2 & 2 & 1 & 1 \\ 1 & 1 & 1 & 0 & 2 & 2 & 2 & 2\end{array}$

$\begin{array}{llllllll}2 & 1 & 1 & 0 & 1 & 1 & 2 & 2\end{array}$

$\begin{array}{llllllll}2 & 1 & 1 & 0 & 1 & 1 & 2 & \end{array}$

$\begin{array}{llllllll}2 & 1 & 1 & 0 & 1 & 1 & 1 & 1\end{array}$

$\begin{array}{llllllll}2 & 2 & 2 & 0 & 1 & 1 & 1 & 1\end{array}$

$\begin{array}{llllllll}1 & 2 & 2 & 0 & 2 & 2 & 2 & 2\end{array}$

$\begin{array}{llllllll}2 & 2 & 2 & 0 & 1 & 1 & 2 & 2\end{array}$

$\begin{array}{llllllll}2 & 2 & 2 & 0 & 1 & 1 & 1 & 1\end{array}$

$\begin{array}{llllllll}1 & 1 & 1 & 0 & 2 & 2 & 2 & 2\end{array}$

\section{I- Stem anatomy}

The stem outline ranged from terete in Calligonum polygonoides, Ruprechtia salicifolia and Ruprechtia laxiflora, ovoid with wavy margin in Persicaria senegalensis, Rumex dentatus and Rumex vesicarius and pentagonal in the rest. Hypodermis was absent in Persicaria senegalensis, Rumex dentatus and Rumex vesicarius and present in the remainders. Pericycle showed two types; parenchymatous in Rumex dentatus and Rumex vesicarius and fibrous in the rest. Vascular structure of stem was a continuous ring in Calligonum polygonoides, Ruprechtia salicifolia and Ruprechtia laxiflora while isolated bundles were found in the remainders.

\section{II- Leaf anatomy}

The petiole outline demonstrates that the studied species can be distinguished into four patterns; semi-terete with wavy margin in Rumex dentatus and Rumex vesicarius, half circle with wavy margin in Persicaria senegalensis, half circle with 2 projections in Antigonon guatimalense and Antigonon leptopus and oval in the rest. Epidermis was mixed radially and tangentially in Rumex dentatus and Rumex vesicarius and radially only in the remainders. Main vascular bundles were only one in Persicaria senegalensis and more than one in the rest. Arrangement of vascular bundles showed two types; in a circle in Persicaria senegalensis, Ruprechtia salicifolia and Ruprechtia laxiflora and irregularly scattered in the remainders.

Blade was isobilateral in Antigonon guatimalense and Antigonon leptopus and dorsiventral in the remainders. Epidermis was mixed in Rumex dentatus and Rumex vesicarius and radially only in the remainders. Vascular bundle sheath composed of collenchyma cells in Persicaria senegalensis, Rumex dentatus and Rumex vesicarius while composed of sclerenchyma cells in the rest. Main vascular bundles is one in Persicaria senegalensis, Rumex dentatus and Rumex vesicarius and more than one in the remainders.

\section{III- Stomata}

The stomata revealed three main types; Anomocytic, anisocytic and paracytic.

1- Anomocytic: present in Rumex dentatus, Rumex vesicarius, Ruprechtia salicifolia and Ruprechtia laxiflora and absent in the remainders.

2- Anisocytic: present in Antigonon guatimalense and Antigonon leptopus and absent in the remainders.

3- Paracytic: present in Persicaria senegalensis 


\section{IV- trichomes}

This work showed that the studied species recorded five types of non-glandular trichomes and three types of glandular trichomes.

\section{Non-glandular trichomes}

1- Unicellular papillose: present in Persicaria senegalensis, Rumex dentatus and Rumex vesicarius and absent in the remainders.

2- Simple with long broad, blunt \& smooth apical cell: present in Rumex dentatus, Rumex vesicarius, Antigonon guatimalense and Antigonon leptopus and absent in the remainders.

3- Simple with long broad, acute \& smooth apical cell: Present in all species but absent in Persicaria senegalensis only.

4- Uniseriate: Present in Persicaria senegalensis, Rumex dentatus and Rumex vesicarius and absent in the remainders.

5- Bristle: Present in Persicaria senegalensis only and absent in the rest.

\section{Glandular trichomes}

1- Unicellular stalk and bicellular head: Present in Antigonon guatimalense and Antigonon leptopus and absent in the remainders.

2- Short unicellular stalk and multicellular head: Present in Antigonon guatimalense, Antigonon leptopus, Ruprechtia salicifolia and Ruprechtia laxiflora and absent in the remainders.

3- Sessile glands: Present in Persicaria senegalensis, Rumex dentatus and Rumex vesicarius and absent in the remainders.

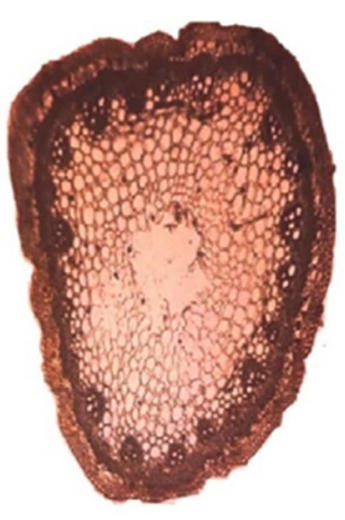

Persicaria senegalensis

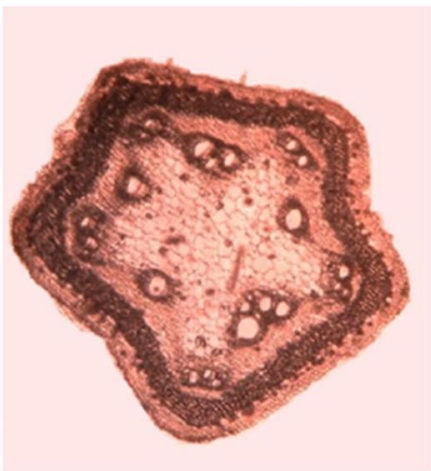

Antigonon guatimalense

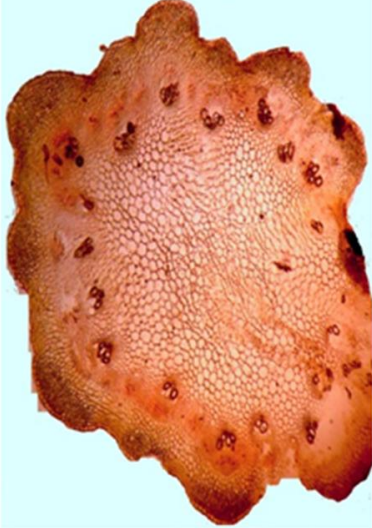

Rumex vesicarius

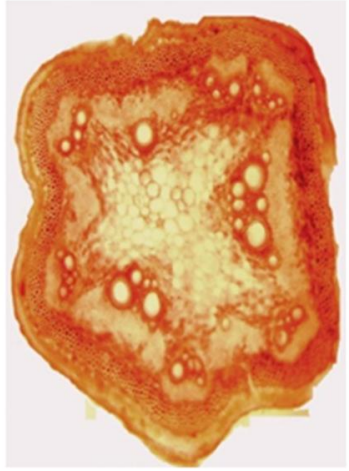

Antigonon leptopus

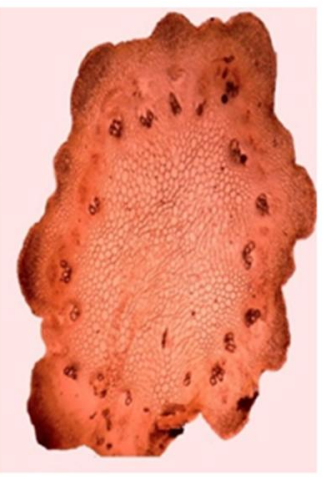

Rumex dentatus

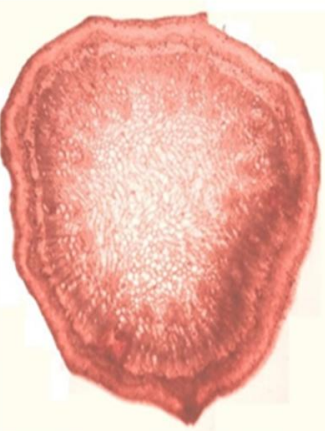

Ruprechtia laxiflora

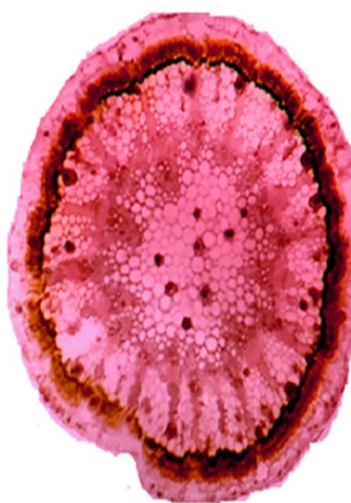

Calligonum polygonoides

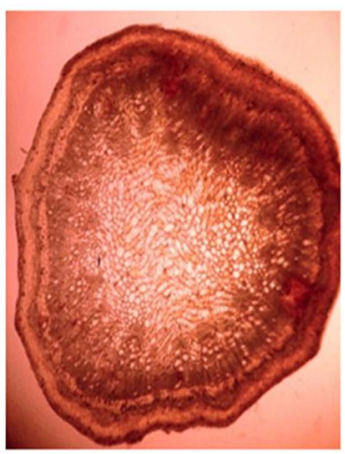

Ruprechtia salicifolia

Plate 3: T. S. in Stem outlines of the studied species 


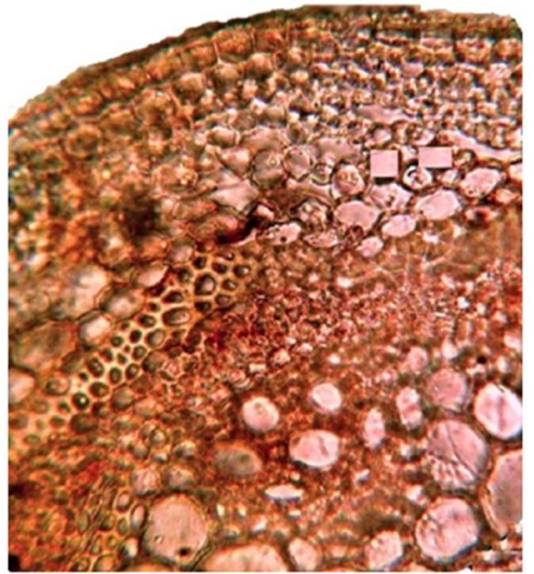

Persicaria senegalensis

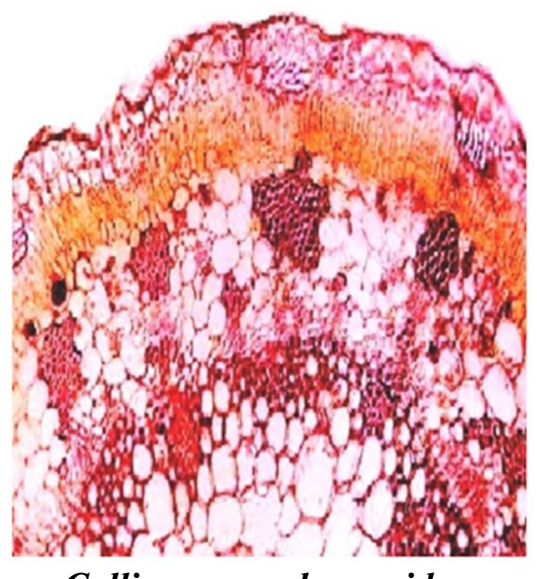

Calligonum polygonoides

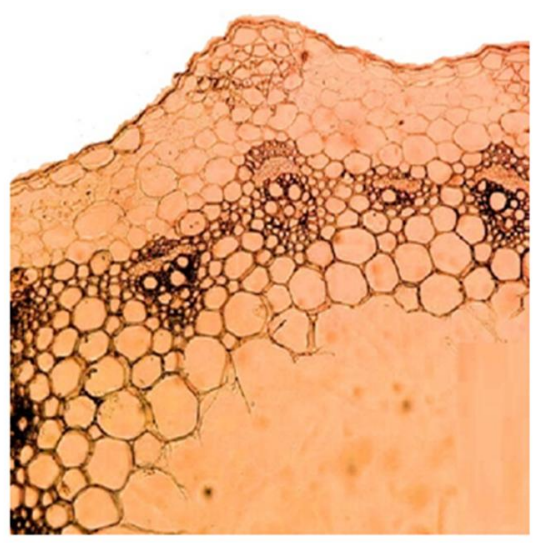

Rumex vesicarius

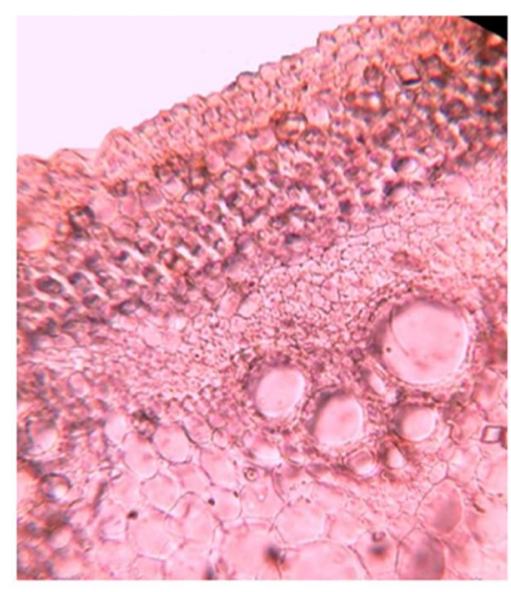

Antigonon guatimalense

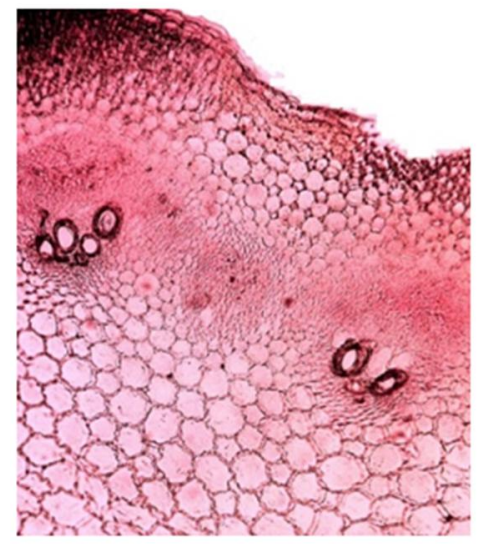

Rumex dentatus

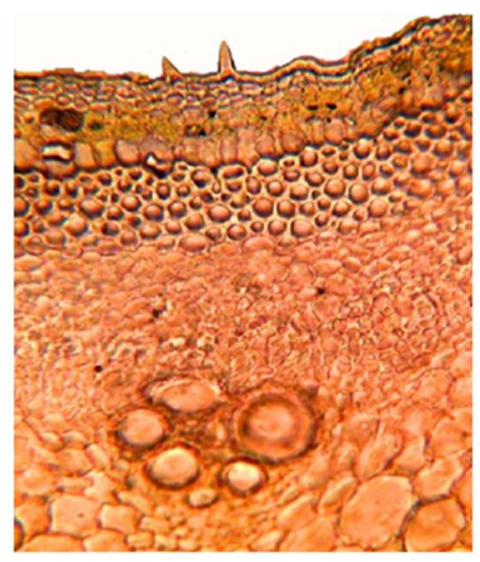

Antigonon leptopus

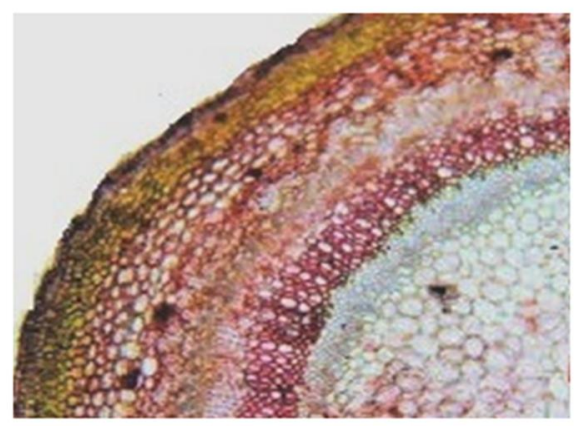

Ruprechtia laxiflora

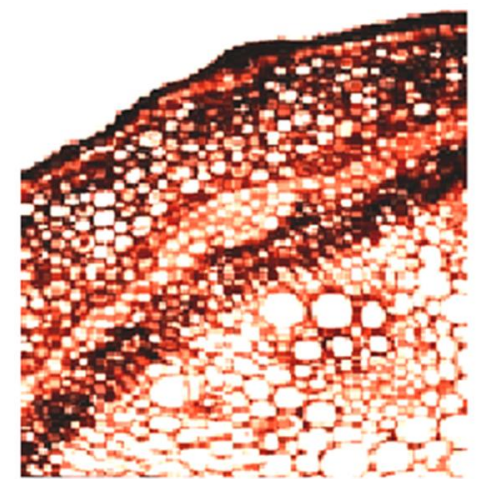

Ruprechtia salicifolia

Plate 4: T. S. in Stem sectors of the studied species 


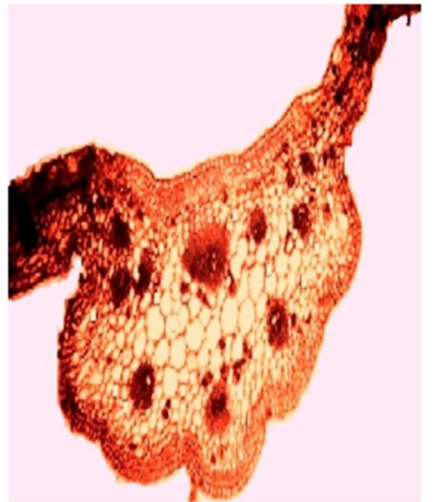

Persicaria senegalensis

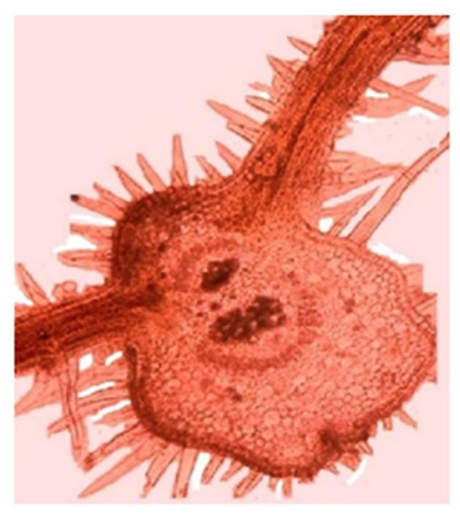

Antigonon guatimalense
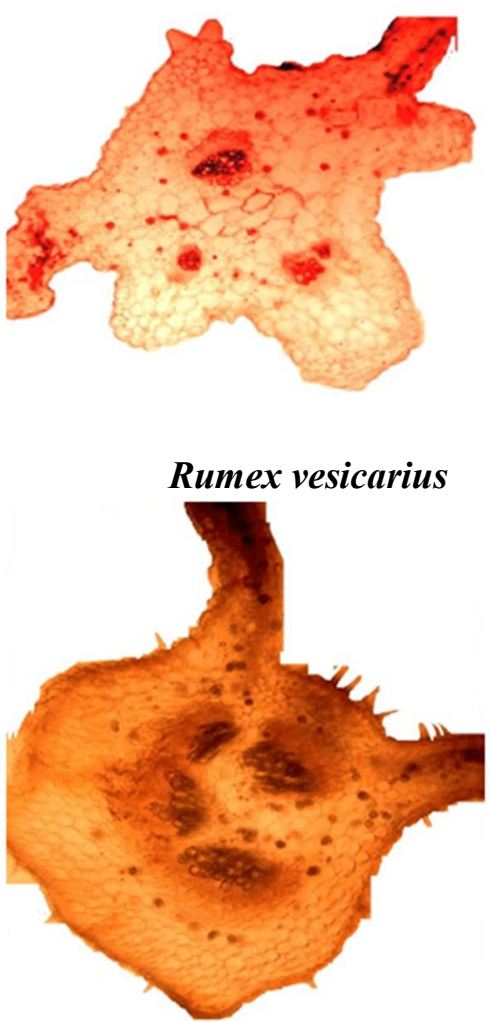

Antigonon guatimalense

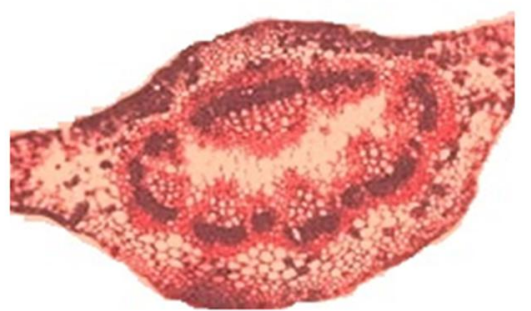

Ruprechtia salicifolia

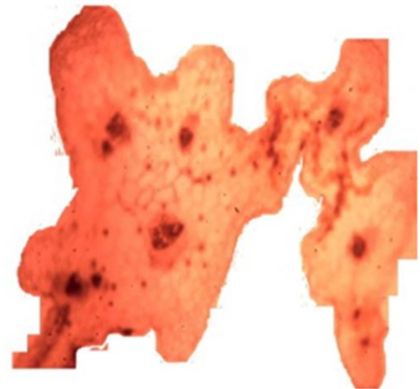

Rumex dentatus

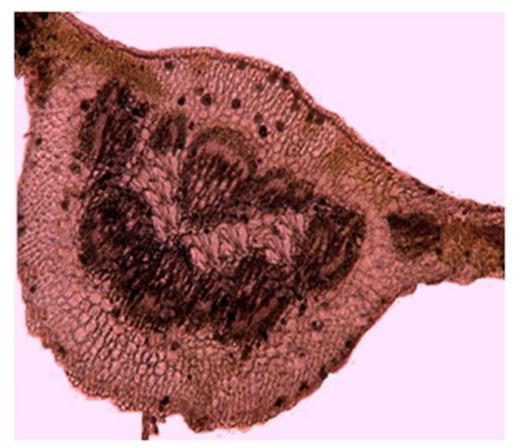

Ruprechtia laxiflora

Plate 5: T. S. in Leaf blades of the studied species

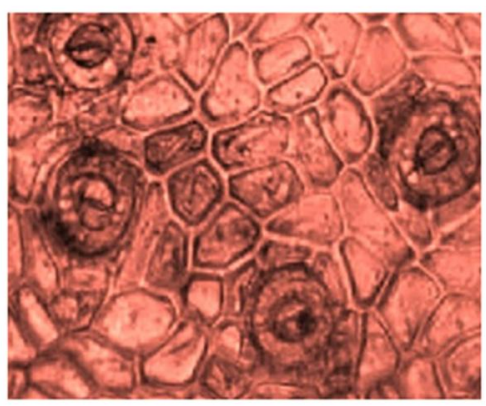

Persicaria senegalensis

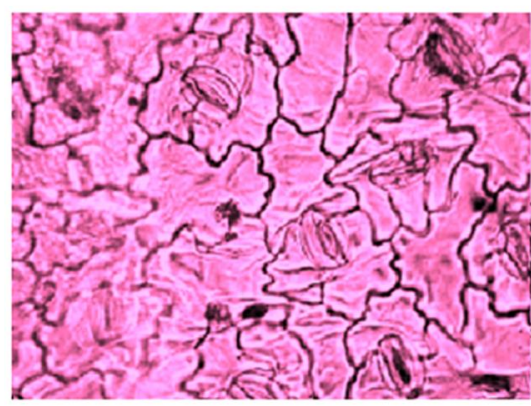

Rumex vesicarius

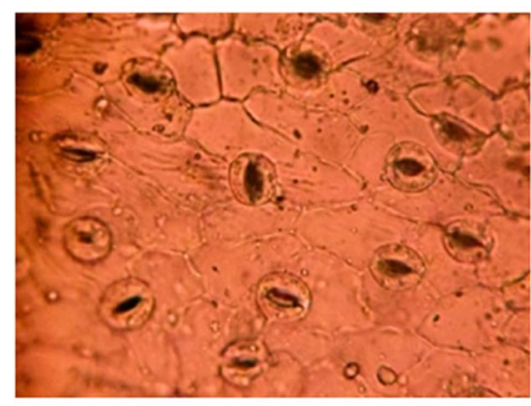

Antigonon guatimalense

Plate 6: The main types of stomata in the studied species 


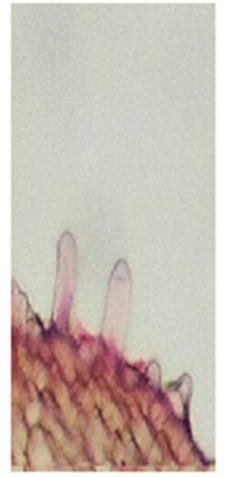

Persicaria senegalensis

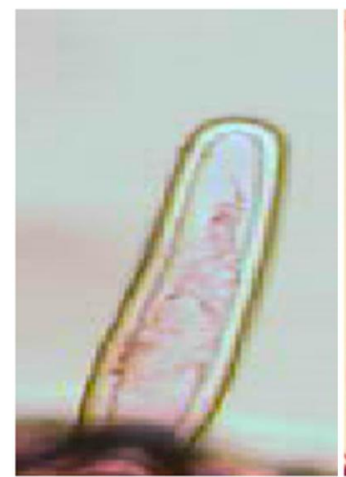

Rumex vesicarius

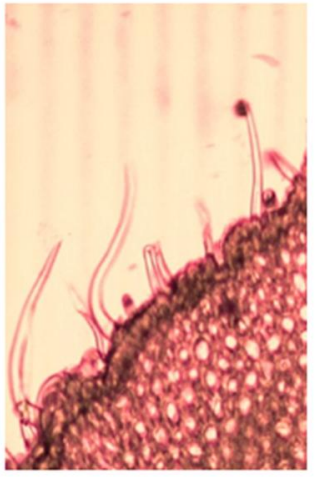

Antigonon guatimalense

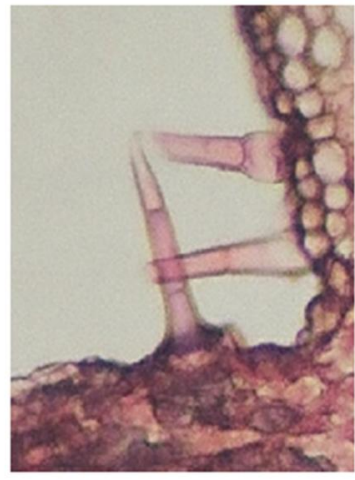

Antigonon leptopus

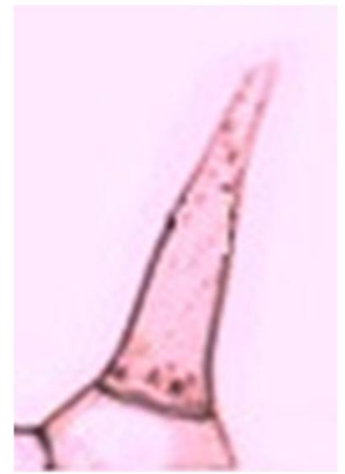

Persicaria senegalensis

Plate 7: The main types of non-glandular trichomes in the studied species

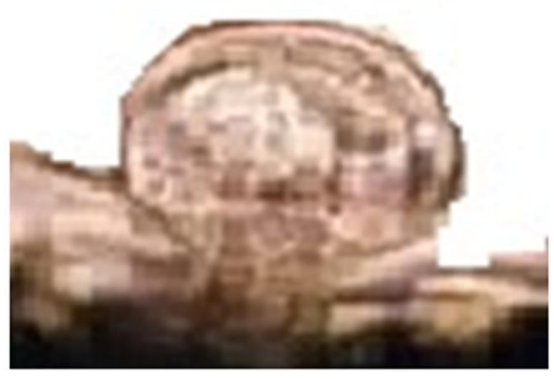

Rumex dentatus

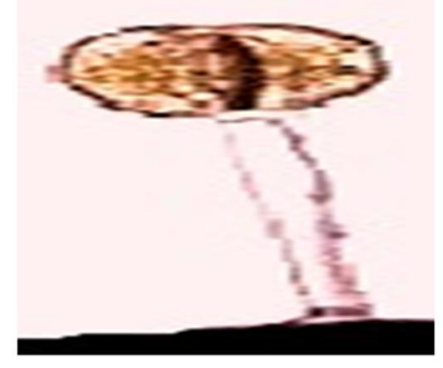

Antigonon leptopus

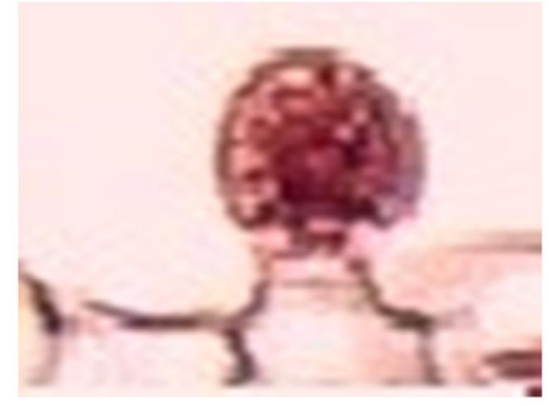

Ruprechtia laxiflora

Plate 8: The main types of glandular trichomes in the studied species

\section{c- Numerical Analysis}

The characters from macro and micro-morphological investigations for 8 species of Polygonaceae were used for numerical analysis by using the method of clustering as a tool in the identification of the studied species and in distinguishing the taxonomic relationships among the studied species. The results of clustering analyzed by the agglomeration of Schedule measure distance and similarity using average linkage between groups by SPSS program.

\section{a- Macro-morphological characters}

The numerical analysis of 21 macro- morphological characters showed that the studied species were grouped into two major clusters as shown in Fig. (1). The first cluster (I) consisted of one species Calligonum polygonoides represented the tribe Atraphaxidinae. The second cluster (II) comprises the remainders.

The second cluster divided into two sub clusters. The first sub cluster represented the subfamily Polygonoideae and divided into two groups. The first group contained Persicaria senegalensis represented the tribe Persicarieae. The second group encluded Rumex dentatus and Rumex vesicarius represented the tribe Rumiceae. The second sub cluster represented the subfamily Coccoloboideae and divided into two groups. The first group contained Antigonon guatimalense and Antigonon leptopus which represented the tribe Coccolobeae. The second group contained Ruprechtia salicifolia and Ruprechtia laxiflora represented the tribe Triplarideae.

\section{- Degree of similarity among the studied species:}

The data presented in (Table 5) showed that Rumex dentatus and Rumex vesicarius gave the highest degree of similarity ratio $73.4 \%$ followed by $72.6 \%$ between Antigonon guatimalense and Antigonon leptopus and $42.8 \%$ between Ruprechtia salicifolia and Ruprechtia laxiflora. The highest degree of similarity ratio for Persicaria senegalensis was $32.4 \%$ with Rumex vesicarius and $30.2 \%$ 
with Rumex dentatus. The highest degree of similarity ratio for Calligonum polygonoides was $26.7 \%$ with Antigonon guatimalense and $25.4 \%$ with Rumex dentatus.

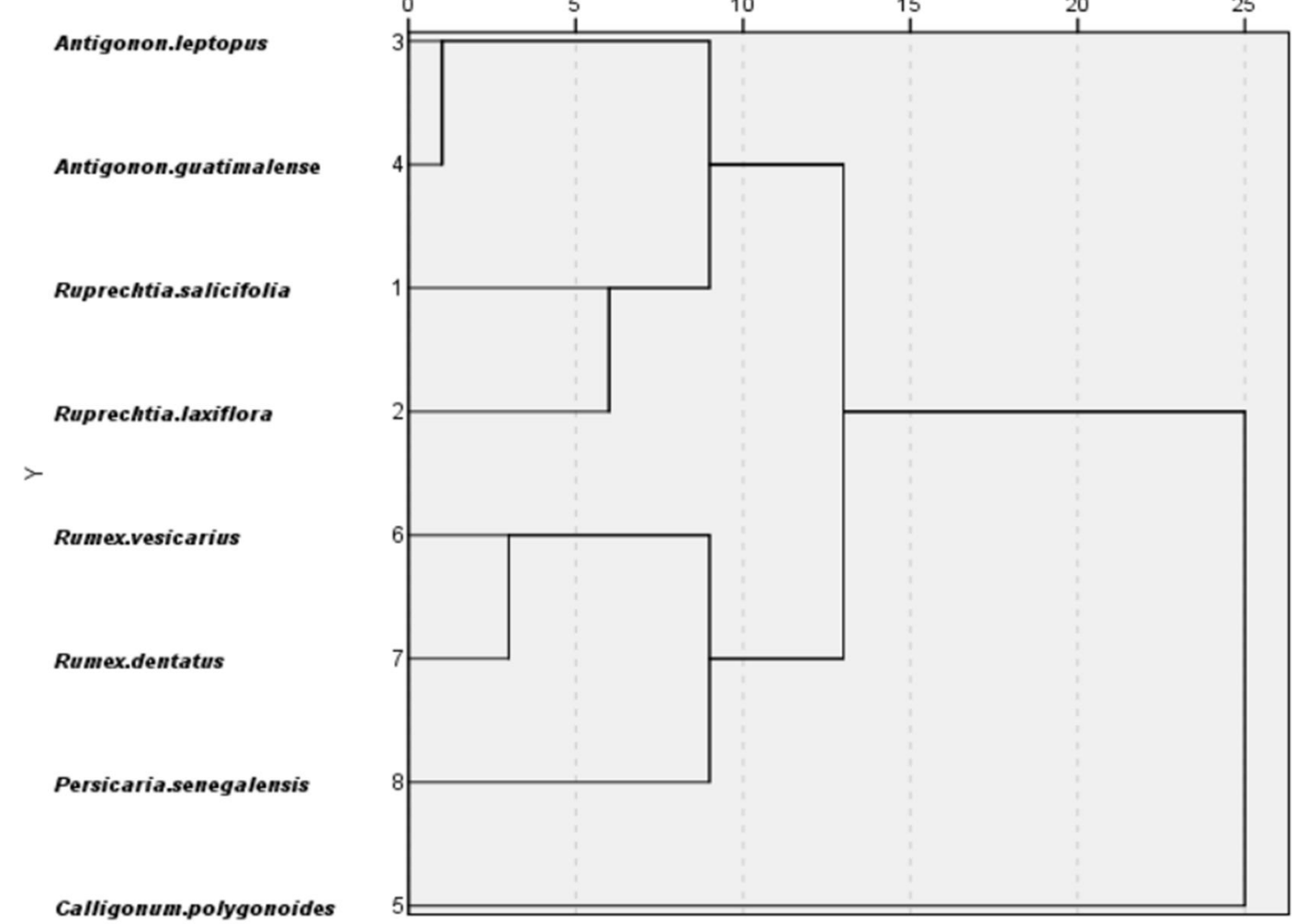

Fig. 1: Dendrogram showed similarity value of the studied species based on macro-morphological characters

Table 5: Proximity matrix showed similarity value of the studied species based on macro-morphological characters

\begin{tabular}{|c|c|c|c|c|c|c|c|c|}
\hline & 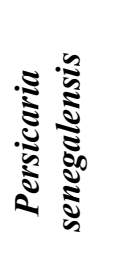 & 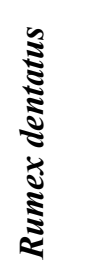 & 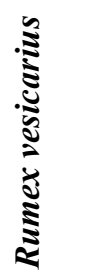 & 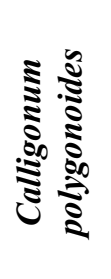 & 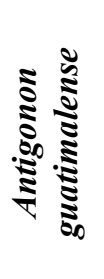 & 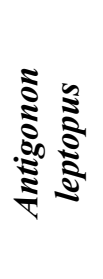 & 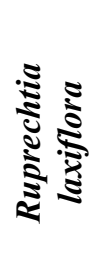 & 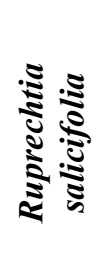 \\
\hline Persicaria senegalensis & 1.00 & 0.302 & 0.324 & 0.090 & 0.196 & 0.206 & 0.104 & 0.187 \\
\hline Rumex dentatus & 0.302 & 1.00 & 0.734 & 0.254 & 0.213 & 0.056 & 0.183 & 0.186 \\
\hline Rumex vesicarius & 0.324 & 0.734 & 1.00 & 0.003 & 0.132 & 0.054 & 0.106 & 0.122 \\
\hline Calligonum polygonoides & 0.090 & 0.254 & 0.003 & 1.00 & 0.267 & 0.243 & 0.075 & 0.004 \\
\hline Antigonon guatimalense & 0.196 & 0.213 & 0.132 & 0.267 & 1.00 & 0.726 & 0.340 & 0.265 \\
\hline Antigonon leptopus & 0.206 & 0.056 & 0.054 & 0.243 & 0.726 & 1.00 & 0.310 & 0.251 \\
\hline Ruprechtia laxiflora & 0.104 & 0.183 & 0.106 & 0.075 & 0.340 & 0.310 & 1.00 & 0.423 \\
\hline Ruprechtia salicifolia & 0.187 & 0.186 & 0.122 & 0.004 & 0.265 & 0.251 & 0.428 & 1.00 \\
\hline
\end{tabular}

\section{b- Micro-morphological characters}

The numerical analysis of 43 micro- morphological characters for 8 species of Polygonaceae showed the same results of Cluster analysis in macro-morphological characters but differ in degree of similarity among the studied species as shown in Fig. (2).

The data presented in (Table 6), showed that Ruprechtia salicifolia and Ruprechtia laxiflora gave the highest degree of similarity ratio $98.6 \%$ followed by $93.2 \%$ between Antigonon guatimalense and 
Antigonon leptopus. Rumex dentatus and Rumex vesicarius showed high degree of similarity ratio $90.3 \%$. The highest degree of similarity ratio for Persicaria senegalensis was $14.8 \%$ with Rumex vesicarius and Rumex dentatus. Moreover the highest degree of similarity ratio for Calligonum polygonoides was $16.3 \%$ with Rumex vesicarius and Rumex dentatus.
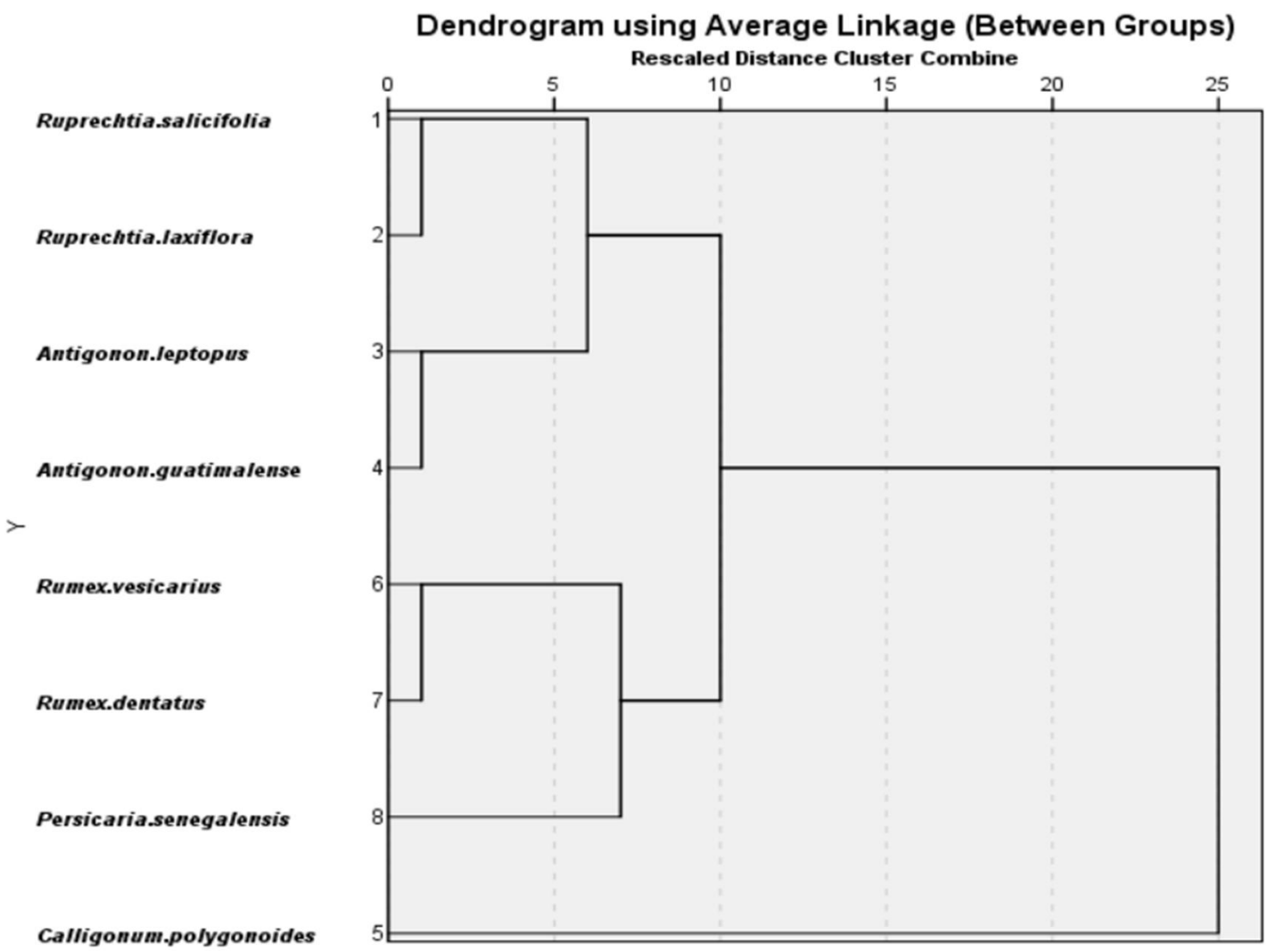

Fig. 2: Dendrogram showed similarity value of the studied species based on micro-morphological characters

Table 6: Proximity matrix showed similarity value of the studied species based on micro-morphological characters

\begin{tabular}{|c|c|c|c|c|c|c|c|c|}
\hline & 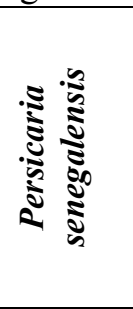 & 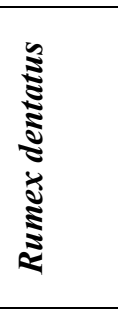 & 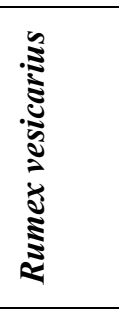 & 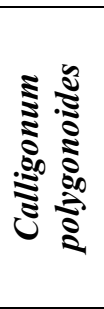 & 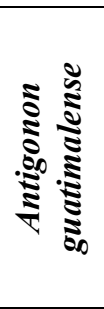 & 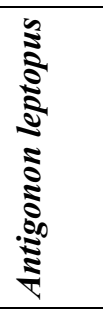 & 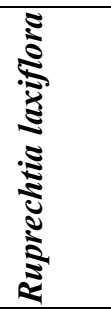 & 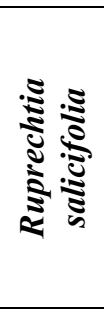 \\
\hline Persicaria senegalensis & 1.00 & 0.148 & 0.148 & 0.068 & 0.056 & 0.017 & 0.084 & 0.084 \\
\hline Rumex dentatus & 0.148 & 1.00 & 0.903 & 0.163 & 0.089 & 0.008 & 0.236 & 0.236 \\
\hline Rumex vesicarius & 0.148 & 0.903 & 1.00 & 0.163 & 0.170 & 0.089 & 0.236 & 0.236 \\
\hline Calligonum polygonoides & 0.068 & 0.163 & 0.163 & 1.00 & 0.012 & 0.012 & 0.036 & 0.036 \\
\hline Antigonon guatimalense & 0.056 & 0.089 & 0.170 & 0.012 & 1.00 & 0.932 & 0.364 & 0.364 \\
\hline Antigonon leptopus & 0.017 & 0.008 & 0.089 & 0.012 & 0.932 & 1.00 & 0.428 & 0.428 \\
\hline Ruprechtia laxiflora & 0.084 & 0.236 & 0.236 & 0.036 & 0.364 & 0.428 & 1.00 & 0.986 \\
\hline Ruprechtia salicifolia & 0.084 & 0.236 & 0.236 & 0.036 & 0.364 & 0.428 & 0.986 & 1.00 \\
\hline
\end{tabular}

\section{Conclusion}

The results of macro- and micro- morphological characters considered Polygonoideae and Coccoloboideae as two separate subfamilies. This study supported the systems of Melchior (1964), Sanchez et al., (2011) and Schuster et al., (2015) while was not agreed with the systems of Jaretzky (1925) Reveal (1989) Brandbyge (1992) and Freeman and Reveal (2005) in including Coccoloboideae 
within Polygonoideae. On the other hand the results agreed with Roberty and Vautier (1964) in separating Calligonoideae as a distinct subfamily.

\section{Acknowledgment}

I would like to thank Prof. Dr. Nael M. Fawzy (Flora and Phytotaxonomy Researches Department, HRI, ARC.) and Mrs. Therza Labeb for their support and co-operation.

\section{References}

Ayodele, A.E. and J.D. Olowokudejo, 2006. The family Polygonaceae in West Africa: Taxonomic significance of leaf epidermal characters. South African J. Bot., 3: 442-459.

Bailey, L.H., 1949. Manual of cultivated plants. The Macmilan company, New York. pp.: 347-351.

Bentham, G. and J. D. Hooker, 1880. Polygonaceae. Genera Plantarum L, Reeve \& Co., London. pp.: 769.

Boulos, L., 1999. Flora of Egypt. Al Hadara Publishing, Cairo, Egypt. vol.1: 21-34.

Brandbyge, J., 1992. Reforestation de los Andes ecuatorianos con especies nativas. CESA, Quito, Ecuador. pp.: 90

Brummitt, R.K., 1992. Vascular Plant Families and Genera. Royal Botanic Garden, Kew, England. pp.: 804.

Buchinger, M., 1957. Nota sobre la subdivision de la familia de las Poligonaceas Boletín de la Sociedad Argentina. 7, pp. 42-43.

Dilcher, D. L.,1974. Approaches to the identification of Angiosperm leaf remains Bot. Rev. 40 (1): 86 $-116$.

Freeman, C.C. and J.L. Reveal, 2005. Polygonaceae, vol. 5, pp.: 216-221.

Flora of North America, Editorial committee, Oxford University Press, Oxford.

Haraldson, K., 1978. Anatomy and Taxonomy in Polygonaceae subfam. Polygonoideae Meissn. Emend. Jaretzky. Symbolae Botanicae Upsalienses, 22 (2), pp.: 1-95

Heywood, V.H., 1978. Flowering Plants of the World, Oxford University Press, Oxford. pp.: 336.

Hutchinson, J. and J. M. DaLziel, 1954. Flora of West Tropical Africa, vol. 1. Crown agents for Overseas Government and Administrations, London. pp.: 295.

Jaretzky, R., 1925. Beiträge zur systematik der Polygonaceae unter berucksichtigungdes oxymethylanthrachinon-vorkommens. Feddes Repertorium Specierum Novarum Regni Vegetabilis 22: 49-83.

Jussieu, A. L., 1789. Genera plantarum. Herrisant and Barrois: Paris, France. pp.: 82.

Lersten, N. R. and J.D. Curtis, 1992. Foliar anatomy of Polygonum (Polygonaceae): Survey of epidermal and selected internal structures. Plant Syst. E vol., 182: 71-106.

Lindley, J., 1932. Flora medica; A botanical account of all the more important plants used in medicine. Longman, London. pp.: 527- 545.

Linnaeus, C., 1753. Species Plantarum (Facsimile of 1st ed. 1957) Adlard \& Sons, London.

Melchior, H., 1964. A. Engler s Syllabus Der Pflanzenfamilien, Berlin, Nikolassa. vol.I1: 75- 79.

Metcalfe, C. R. and L. Chalk, 1950. Anatomy of the Dicotyledons, Oxford University Press, Oxford. pp.: 724.

Metcalfe, C. R. and L. Chalk, 1979. Anatomy of the dicotyledons (1): 55, Clarenedon Press, Oxford.

Nassar, M. A. and El-Sahhar, K. F. 1998. Botanical preparation and Microscopy (Microtechnique), Academic Bookshop, Dokki, Giza, Egypt. pp.: 219 (In Arabic).

Noor, N. M., H. Bunawan and N. Talip, 2011. Foliar anatomy and micromorphology of Polygonum minus Huds. and their taxonomic implications. AJCS 5(2):123-129.

Pandey, B. P., 1997. A text book of botany Angiosperms. S. Chand and Company LTD. Ramnagar, New Delhi.

Reveal, J. L., 1989. The Eriogonoid flora of California (Polygonaceae: Eriogonoideae). Phytologia 66: $295-414$.

Roberty, G. S. and M. Vautier, 1964. Les genres de Polygonacées. Boissiera10: 7-128. 
Ronse Decraene, L.P. and J.R. Akeroyd, 1988. Generic limits in Polygonum and related genera (Polygonaceae) on the basis of floral characters. Botanical Journal of the Linnean Society, 98, pp.: 321-371.

Sanchez, I. and K.A. Kron, 2008. Phylogenetics of Polygonaceae with an Emphasis on the Evolution of Eriogonoideae. Syst. Bot., 33: 87-96.

Sanchez, A., T.M. Schuster, J.M. Burke, and K.A. Kron, 2011. Taxonomy of Polygonoideae (Polygonaceae): A new tribal classification. Taxon, 60: 151-160.

Schuster Tanja M., Reveal, L. James, J. Bayly Michael and K.A. Kron, 2015. An updated molecular phylogeny of Polygonoideae (Polygonaceae): Relationships of Oxygonum, Pteroxygonum, and Rumex, and a new circumscription of Koenigia. Taxon, 64 (6): 1188-1208.

Tãckholm, V., 1974. Students' flora of Egypt. $2^{\text {nd }}$ ed. Cairo Univ. Publication, Corporative Printing Co., Beirut. pp.: 58- 68 .

Takhtajan, A., 1980. Outline of the Classification of Flowering Plants (Magnoliophyta), New York Botanical Garden, New York, pp.: 359. 